\title{
Development, economic viability and attributes of lamb carcass \\ from confined animals fed on different amounts of crude glycerin
}

\author{
Desempenho, viabilidade econômica e características de carcaça \\ de cordeiros alimentados em confinamento com rações contendo \\ diferentes teores de glicerina bruta
}

\author{
Fabiola Cristine de Almeida Rego ${ }^{1 *}$; Monica Chaves Françozo ${ }^{2}$; \\ Agostinho Ludovico ${ }^{3}$; Lisiane Dorneles de Lima ${ }^{4}$; Flavio Guiselli Lopes ${ }^{1}$; \\ Lais Belan²; Marcelo Diniz dos Santos ${ }^{5}$; Marilice Zundt ${ }^{6}$; \\ Luiz Fernando Coelho Cunha Filho ${ }^{1}$; Camila Constantino ${ }^{7}$
}

\begin{abstract}
The current study aims to assess the effect from crude glycerin inclusion $(0,7,14$, and $21 \%$ dry matter) in the diet of slaughtered lamb on their development, nutrient consumption, biometrical measures, diet economic viability and carcass features. Thirty two (32) non-castrated male Texel lambs were used in the study, they presented mean initial weight $15.9 \pm 4.1$ kilos and were distributed in casual outlining. They were fed with four treatments, with 8 repetitions. Animals were slaughtered when they reached approximately 35 kilos. The mean total weight gain was 20.72 kilos and mean daily weight gain was 260 grams. No changes resulted from glycerin use. The carcass performance was similar among treatments $(\mathrm{P}>0.05)$ and the cold carcass performance $(\mathrm{CCP})$ was $44.68 \%$. There were no effects $(\mathrm{P}>0.05)$ on the loin eye area (LEA) and on fat thickness (FT); they showed averages of $13.66 \mathrm{~cm}^{2}$ and $0.84 \mathrm{~mm}$, respectively. Nutrition cost per animal during the whole confinement period varied between R $\$ 82.60$ (eighty-two Reais and forty-eight cents) to $\mathrm{R} \$ 92.48$. The smallest nutrition amount consisted of $21 \%$ crude glycerin. The gross profit ranged from $\mathrm{R} \$ 30.75$ to $\mathrm{R} \$ 34.01$ per animal, for feed without glycerin and $21 \%$ glycerin, respectively. Animal development was not impacted by glycerin introduction, even with decrease on dry and organic mass consumption. The result showed that crude glycerin inclusion might be used in lambs' diet. Whenever there are big amounts of feed involved in the process, the $21 \%$ crude glycerin addition may be an interesting cost reduction. Seventy eight percent (78\%) glycerol crude glycerin to replace corn-based feed in confined lambs' diet appeared to be nutritionally and economically viable.
\end{abstract}

Key words: Co-products, expenses, weight gain, glycerol, sheep, carcass performance

1 Profs. Drs. Titulares, Programa de Mestrado em Saúde e Produção de Ruminantes, Universidade Norte do Paraná, UNOPAR, Arapongas, PR, Brasil. E-mail: fabiolaregogrecco@gmail.com; lopesufv@yahoo.com.br; luiz.cunha@unopar.br

2 Discentes do Curso de Mestrado em Saúde e Produção de Ruminantes, UNOPAR, Arapongas, PR, Brasil. E-mail: monicacf. vet@hotmail.com; lais_belan@hotmail.com

3 Prof. Dr. Titular, Programa Mestrado em Ciência e Tecnologia de Leite e Derivados, UNOPAR, Londrina, PR, Brasil. E-mail: agostinho@rocketmail.com

4 Dra Pesquisadora, EMBRAPA Caprinos e Ovinos, Sobral, CE, Brasil. E-mail: lisiane.lima@embrapa.br

5 Dr., Programa de Mestrado em Biociência Animal, Universidade de Cuiabá, UNIC, Cuiabá, MT, Brasil. E-mail: marcelo.diniz@, kroton.com.br

6 Dra ${ }^{\mathrm{a}}$, Pesquisadora Associada do Programa de Pós-Graduação em Ciência Animal, Universidade do Oeste Paulista, UNOESTE, Presidente Prudente, SP, Brasil. E-mail: mari@unoeste.br

7 Discente de Pós Doutorado; Programa PNPD/CAPES; Universidade Estadual de Londrina UEL, Londrina, PR, Brasil. E-mail: caconstantino@hotmail.com

* Author for correspondence 


\section{Resumo}

O objetivo desta pesquisa foi avaliar o efeito dos teores de inclusão de glicerina bruta $(0,7,14$, e $21 \%$ da matéria seca) na dieta de cordeiros em terminação, sobre o desempenho, o consumo de nutrientes, as medidas biométricas, a viabilidade econômica da dieta e características da carcaça. Utilizou-se 32 cordeiros machos não castrados da raça Texel, com peso médio inicial de 15,9 $\pm 4,1 \mathrm{~kg}$, distribuídos em delineamento inteiramente casualizado, com quatro tratamentos e oito repetições. Ao atingir o peso médio de $35 \mathrm{~kg}$, os animais foram abatidos. O ganho de peso total foi em média 20,72 kg e o ganho de peso médio diário foi de $260 \mathrm{~g}$ e não sofreram alterações com o uso da glicerina. As características de rendimento de carcaça avaliadas se assemelharam entre os tratamentos $(\mathrm{P}>0,05)$ e o rendimento de carcaça fria (RCF) foi em média 44,68\%. Não houve efeito $(\mathrm{P}>0,05)$ para área de olho de lombo (AOL) e espessura de gordura (EG), apresentando médias de $13,66 \mathrm{~cm}^{2}$ e $0,84 \mathrm{~mm}$, respectivamente. Os custos com alimentação por animal no período total de confinamento variaram entre $\mathrm{R} \$ 82,60$ a $\mathrm{R} \$ 92,48$, sendo o menor valor para o tratamentos contendo $21 \%$ de glicerina bruta. A margem bruta de lucro variou de $\mathrm{R} \$ 30,75$ a $\mathrm{R} \$ 34,01$ por animal, para ração sem glicerina e com $21 \%$ de glicerina, respectivamente. O desempenho animal não foi afetado pela inclusão de glicerina bruta, mesmo com a redução ocorrida no consumo de matéria seca e matéria orgânica, mostrando que a inclusão da glicerina bruta pode ser utilizada na dieta para ovinos. A inclusão de $21 \%$ de glicerina bruta pode ser uma alternativa interessante quando se tratar de grandes volumes de ração, mostrando economicidade ao sistema. O uso da glicerina bruta, contendo $78 \%$ de glicerol, em substituição ao milho em rações para cordeiros confinados mostrou-se viável sob o ponto de vista nutricional e econômico.

Palavras-chave: Coprodutos, custos, ganho de peso, glicerol, ovinos, rendimento de carcaça

\section{Introduction}

The increase on lamb farming in Brazil on the last decades pinpoints that the activity has positive perspectives regarding economic potential. Similarly, there has been a growing demand for high quality lamb meat, mainly in large urban centers. It is necessary that farmers adopt techniques able to standardize the carcass and the cuts available in the consumer market, in order to achieve the production demand for high quality ovine meat. Besides, there is the need to rearrange many points in the production chain (LAGE et al., 2010).

One of the options to meet the quality and quantity demands for this meat is slaughtered confined lamb. According to Zanette and Neumann (2012), this system results in higher quality products presenting appropriate carcass finishing, higher carcass performance and higher standardization of lamb cuttings. The method is used to increase lamb farming productivity and it has positive results on carcass quality and on the amount of meat during the off-season (PRADO et al., 2010).

The production cost of conventionally fed confined animals is still considered to be high
(LAGE et al., 2010), that is why there has been grown concern about alternative food to replace some feed ingredients in lams' diet, although without damaging the animal's nutrition consumption and development. Therefore, biodiesel-processed glycerin is one of the agro industrial by-products with potential to be used in ruminant feeding (HANSEN et al., 2009).

Crude glycerin has been studied as an option to replace energy supply in ruminant diets and it can be rated according to glycerin level - low purity (50 to $70 \%$ ), mid purity (80 to $90 \%$ ) and high purity degree (over 99\% glycerol) (SUDEKUM, 2008). Thus, processing is actually what rules glycerin purity degree.

According to Reis et al. (2001), ovine species stand out for their efficiency on weight gain and carcass quality in the first six months of life, time when their meat presents excellent protein source with high biological value. According to Costa et al. (2004), carcass features depend on inherited and on the environmental elements animals are submitted to. It explains why the selected animals have to be of high reproductive efficiency, of efficient 
conversion from food to meat and of ideal patterns, so the desired carcass composition is transmitted to their offspring.

As aforementioned, the current study aims to assess the effects from adding crude biodieselprocessed glycerin on the production performance, carcass features and economic viability of slaughtered confined lamb treated with different glycerin levels.

\section{Material and Methods}

The experiment was conducted in the experimental area of Universidade Norte do Paraná campus, located in Arapongas, from September $13^{\text {th }}$ to December $9^{\text {th }} 2012$. The experimental period lasted 88 days - the first 14 days were carried out for lambs' adjustment to the experimental conditions. Animals were dewormed before starting the experiment. The research was approved by Ethics Committee for Animal Use of UNOPAR (CEA) protocol 004/12, and it meets the ethics principles of animal testing.

Thirty-two half-breed-male Texel lambs, presenting mean initial weight $15.9 \pm 4.1$ kilos were used as subject. Animals were hosted in four collective stalls containing feeder and drinker. A casual outlining composed of four treatments and eight repetitions was used and it had the same glycerin degree as that in the diet of slaughtered lambs. Crude glycerin replaced 0, 7, 14 and 21\% of corn's total dry matter in the diet.

The complete diet had $40 \%$ of voluminous and $60 \%$ concentrated dry base (Table 1 ). The feed was developed to meet the nutrition requirements of lambs weighting from approximately10 to 30 kilos, according to NRC (2007).

Table 1. Ingredients proportion and chemical composition of experimental feeds (\% of DM) given to e slaughtered confined lamb fed on feed containing different degrees of crude glycerin.

\begin{tabular}{lcccc}
\hline & \multicolumn{4}{c}{ Crude glycerin levels $^{\mathbf{1}}$} \\
\cline { 2 - 4 } & 0 & 7 & 14 & 21 \\
\hline Ingredients & \multicolumn{3}{c}{ \% Dry matter } & 41.35 \\
\hline Corn silage (\%) & 41.35 & 41.35 & 41.35 & 12.23 \\
Corn (\%) & 37.67 & 29.19 & 20.71 & 21.32 \\
Soy bran (\%) & 16.88 & 18.36 & 19.84 & 2.70 \\
Mineral salt (\%) & 2.70 & 2.70 & 2.70 & 1.40 \\
Limestone (\%) & 1.40 & 1.40 & 1.40 & 21.00 \\
Glycerol (\%) & 0.00 & 7.00 & 14.00 & 52.01 \\
\hline Chemical composition ${ }^{2}$ & & & 50.59 & 6.26 \\
\hline DM (\%) & 52.08 & 50.49 & 6.04 & 3.34 \\
MM (\%) & 5.67 & 6.47 & 1.89 & 10.70 \\
EE (\%) & 2.49 & 2.04 & 31.70 & 75.96 \\
NDF (\%) & 33.50 & 31.60 & 10.70 & 45.58 \\
ADF (\%) & 11.60 & 11.30 & 75.77 & 30.38 \\
TC (\%) & 78.16 & 76.76 & 44.18 & 15.40 \\
NFC (\%) & 44.49 & 44.88 & 31.59 & 14.80 \\
FC (\%) & 3.70 & 31.88 & 14.50 & 2.60 \\
CP (\%) & 15.50 & 14.60 & 14.50 & 61.93 \\
NDIP (\%) & 9.69 & 9.17 & 15.1 & 1.75 \\
ADIP (\%) & 21.60 & 12.20 & 63.41 & \\
LIG(\%) & 2.69 & 2.46 & 63.04 & \\
TDN (\%) & 61.21 & & & \\
\hline
\end{tabular}

${ }^{1} 0 \%$ glycerin replacing corn in the diet; $7 \%$ glycerin replacing corn in the diet; $14 \%$ de glycerin replacing corn in the diet; $21 \%$ glycerin replacing corn in the diet. ${ }^{2}$ - DM -dry matter; MM - mineral material. EE - Ether extract. NDF Neutral detergent fiber. $\mathrm{ADF}$ - acid detergent fiber. TC - total carbohydrate. NFC - non-fiber carbohydrate. FC - fiber carbohydrate. CP - crude protein. NDIP - neutral-detergent insoluble protein. ADIP - acid-detergent insoluble protein. LIG - lignin. TDN - Total digestive nutrients. 
Glycerin was acquired from Biopar Bioenergia of Paraná, a company located in Rolândia. Physical-chemical characteristics are shown in Table 2. Animals were weighted every 21 days, before the first feed, at the beginning and during the experimental period and it allowed monitoring animals' development. Animals were fed twice a day -8 A.M and 4 P.M. Approximately 10 to $15 \%$ of the total of supplied food was wasted. The supplied food and its waste were daily weighted by batch. This control procedure allowed estimating animals' mean daily consumption. The consumed dry matter (DMC), crude protein (CPC) and ether extract (EEC) were estimated using data from the animals subjected to the herein described treatment.

Table 2. Crude glycerin physical-chemical features.

\begin{tabular}{lc}
\hline \multicolumn{1}{c}{ Item } & Component level \\
\hline Water level (\%) & 6.4 \\
Glycerol level (\%) & 78 \\
$\mathrm{pH}($ scale) & 6.64 \\
$\mathrm{NaCl}(\%)$ & 0.65 \\
Methanol (\%) & 0.6 \\
\hline
\end{tabular}

Source: Biopar - Bioenergia do Paraná.

Samples of the offered feed were collected during the feeding process, each 15 days, thus totaling 4 experimental feed used to brotomology analysis. Mean results are shown in Table 1. Leftovers were weighted in a daily basis and a small part of it was withdrawn to gather a specific sample for each feeding.

Samples were air dried in greenhouse under $55^{\circ} \mathrm{C}$, for 72 hours. Next, they were processed in Willey mill (1 mm sieve) to assess dry matter (DM), mineral matter $(\mathrm{MM})$, organic matter $(\mathrm{OM})$, crude protein $(\mathrm{CP})$ and ether extract (EE) levels, according to AOAC (1990). The amount of neutral detergent fiber (NDF) and acid detergent fiber (ADF) were set according to Van Soest et al. (1991). Such analyses were done in the Bromotology Lab of Universidade Norte do Paraná.

Carbohydrate levels were estimated according to Sniffen et al. (1992), as well as the total carbohydrate $(\mathrm{TC})=100(\% \mathrm{CP}+\% \mathrm{EE}+\% \mathrm{MM})$ which is an nonfiber carbohydrate (NFC) $=100-(\% \mathrm{NFCcp}+\% \mathrm{CP}$ $+\% \mathrm{EE}+\%$ ashes $)-\mathrm{NDF} c p$ equals the cell wall adjusted to ash and protein.
In order to estimate the total digestive nutrients (TDN) (Table 1), the following formula was used $(\mathrm{NRC}, 2001): \mathrm{NDT}=\mathrm{NFCd}+\mathrm{CPd}+($ FAd $\times 2.25)$ $+\mathrm{NFCd}-7$; in which: NFCd is the non-fiber digestive carbohydrate; $\mathrm{CPd}$ corresponds to the crude digestive protein; FAd means digestive fatty acid; NFCnd corresponds to the NFC adjusted to digestive nitrogen.

As the animals reached 35 kilos LW, they were slaughtered in a cold storage chamber by cerebral concussion to be subsequently eviscerated. Animals were subjected to 16 hours fasting - liquid and solid food-before slaughtering. Next, they were weighted for live weight at slaughter (LWS), total weight gain in the period (Kilos) and daily live weight gain (in grams). The gastrointestinal tract was taken off and the empty body weight was measured (EBW $=$ LWS - gastrointestinal content) after slaughtering. Such measures established the actual performance (AP) from the hot carcass weight-empty body weight interface (SAÑUDO; SIERRA, 1986). Carcasses were weighted (hot carcass weight $=\mathrm{HCW}$ ) after evisceration to determine hot carcass performance $(\mathrm{HCP}=\mathrm{HCW} / \mathrm{LWS} * 100)$. Subsequently, they were 
transferred to a cold chamber $\left(4^{\circ} \mathrm{C}\right)$ where they were stored for 24 hours. By the end of this period, the cold carcasses were weighted (cold carcass weight $=\mathrm{CCW})$ to calculate the cold or commercial carcass performance $\left(\mathrm{CCP}=\mathrm{CCW} / \mathrm{LWS}^{*} 100\right)$, the actual performance $(\mathrm{AP}=\mathrm{WCW} / \mathrm{EBW} \mathrm{X} 100)$, the breaking level to cooling $(\mathrm{BL}=\mathrm{CCW} / \mathrm{HCW} \mathrm{X} 100)$ and the weight loss to cooling $(\mathrm{LC}=(\mathrm{HCWCCW} /$ $\mathrm{HCW}$ * 100).

The Longissimus dorsi muscle was measured between the $12^{\text {th }}$ and $13^{\text {th }}$ thoracic vertebrae, using a caliper to set its length and depth and to estimate the loin eye area (LEA) by applying the following formula: LEA $\left(\mathrm{cm}^{2}\right)=(\mathrm{A} / 2 \times \mathrm{B} / 2) \times \pi$ (SILVA SOBRINHO, 1999). Next, external fat (EF) top thickness data were used. Carcass shaping and finishing were achieved by visual classification based on visual scale from $0-5$ points, according to the methodology by Osório (1998).

The costs of using crude glycerin to replace grained corn were calculated. The individual cost of each ingredient in the diet was taken under consideration in order to estimate dry matter cost per kilo: $\mathrm{R} \$ 350.00 /$ ton of corn silage; $\mathrm{R} \$ 760.00 /$ ton of grained corn; $\mathrm{R} \$ 1.70,00 /$ ton of soy bran; $\mathrm{R} \$ 1.00$ / kilo of mineral salt; R $\$ 0.31 /$ kilo of limestone; R\$0.15/liter of crude glycerin. Batch data were used for food conversion (dry matter consumption of the batch/weight gain of the batch) during all the confinement period. Lamb weight and the live weight price were used for thin lamb acquisition pricing, which was $\mathrm{R} \$ 6.00$ at the time (lamb weight $\mathrm{x}$ R \$6.00) it was calculated. The feeding cost per confined animal was calculated based on the quotient of the offered diet total price by the number of animal in the batch. The price/kilo of live weight gain was the product of food conversion and diet cost per kilo. The total cost per animal was the sum of feed cost per animal and the acquired thin lamb cost. The carcass revenue was the product of mean carcass weight and the carcass' selling price per kilo (R\$13.00). The gross margin per animal was found by the deduction of gross income and total cost per animal.
The statistics analyses of the studied variable were done by variance monitoring at significant level of 5\% probability. Regression analysis was performed using the 9.2 SAS Software (2002).

\section{Results and Discussion}

The mean DMC of animals inside the batches was $906.8 ; 868.6 ; 835.5$ and 819.7 for treatments with $0,7,14$ and $21 \%$ crude glycerin, respectively. All these results were considered to be under the recommended levels by NRC (2007) to this category - which deals with dry matter consumption level close to $1.0 \mathrm{kilo/day.} \mathrm{Lage} \mathrm{et} \mathrm{al.} \mathrm{(2010)} \mathrm{worked}$ with Glycerin levels 0, 3, 6, 9 and 12\% DM and found that consumption reduction was associated to glycerin increase in the diet. Glycerin addition rates were $1,120.71$ and $782.76 \mathrm{~g}$ in the controlled diets, with $12 \%$ crude glycerin, respectively.

Despite many evidences in the literature regarding the fact that crude glycerin reduces feed consumption by the animals, other research show the use of such product did change the consumption. Thus, the expressive decrease observed by Lage et al. (2010) may due to the bad quality of the crude glycerin used in their study $(36.2 \%$ glycerol degree). The present study used 78\% glycerol glycerin degree. It might be the reason why the herein listed results showed no strong decrease on dry matter consumption. Besides, according to Tyson et al. (2004), dirtiness in the recycled oils and the reagents used in the transesterification may have limited the consumption.

Even though literature evidences that crude glycerin reduces feed consumption, animals showed no change in consumption when glycerin was used in some other researches (GUNN et al., 2010; TERRÉ et al., 2011; PELLEGRIN et al., 2012). According to Krehbiel (2008), it may be related to the ability of ruminant's microorganisms to adapt to the glycerol supply, fact that impairs changes in the rumen environment. 
Mean CPB for $0,7,14$ and $21 \%$ treatments were 156.7, 141.0, 131.0 and $148.5 \mathrm{~g}$, respectively. Such results are bellow $167 \mathrm{~g}$, the amount recommended by NRC (2007). CEE presented the following measures: 21.6, 19.6, 18.1 and $17.8 \mathrm{~g}$, respectively, for the four feedings shown in Table 1 . The six percent $(6 \%)$ threshold of total dry matter was not exceeded, as it is recommended in literature (JOHNSON; McCLURE, 1973).

Animal performance data are shown in Table 3. The confinement period (PERC) needed to reach slaughtering weight (SW) of 35 kilos was approximately 79 days and it was not different among the many glycerin degrees used. TWG was approximately 20.72 kilos and DTWG was $260 \mathrm{~g} /$ day; numbers that did not change with glycerin use. These results meet those by Pellegrin et al. (2012) and show that glycerin level in lamb feeding does not change animal's daily weight gain.

Slaughtered animal price (Table 4) was within the standards set by regional cooperatives ( 28 to 35 kilos of live weight) and met literature data; taking in account the same breed which was slaughtered in confinement (CARVALHO et al., 2005).

Table 3. Confinement period (PERC). Total weight gain (TWG). Mean daily weight gain (DAWG) and slaughter weight (SW) of slaughtered confined lambs fed on different levels of crude glycerin.

\begin{tabular}{|c|c|c|c|c|c|c|c|}
\hline Parameters & & Trea & $\mathrm{nts}^{1}$ & & & & \\
\hline & 0 & 7 & 14 & 21 & Average & $\mathrm{CV}^{2}$ & $\mathrm{P}^{3}$ \\
\hline PERC (days) & 77.42 & 79.71 & 79.75 & 79.62 & 79.16 & 8.2 & 0.88 \\
\hline TWG (kilos) & 20.63 & 21.68 & 20.12 & 20.53 & 20.72 & 14.18 & 0.77 \\
\hline DAWG (g/day) & 270.00 & 270.00 & 250.00 & 260.00 & 260.00 & 18.70 & 0.83 \\
\hline
\end{tabular}

${ }^{1} 0 \%$ glycerin replacing corn in the diet; $7 \%$ glycerin replacing corn in the diet; $14 \%$ de glycerin replacing corn in the diet; $21 \%$ glycerin replacing corn in the diet. ${ }^{2}$ Variance ratio. ${ }^{3}$ Probability.

Table 4. Slaughter weight (SW). Empty body weight (EBW). Hot carcass weight (HCW). Cold carcass weight (CCW). Hot carcass performance (HCW). Cold carcass performance (CCP). Biological performance (BP) and break to cooling level (BL) in slaughtered confined lamb nated in confinement, fed on feed containing different crude glycerin levels.

\begin{tabular}{lccccccc}
\hline \multirow{2}{*}{ Parameters } & \multicolumn{9}{c}{ Treatments $^{1}$} \\
\cline { 2 - 8 } & 0 & 7 & 14 & 21 & Average & CV $^{2}$ & $\mathrm{P}^{3}$ \\
\hline SW (kilo) & 36.26 & 38.32 & 35.95 & 36.11 & 36.62 & 14.86 & 0.82 \\
EBW (kilo) & 32.98 & 34.41 & 32.38 & 32.38 & 33.00 & 15.17 & 0.84 \\
HCW (kilo) & 16.56 & 17.22 & 16.43 & 16.64 & 16.70 & 20.05 & 0.97 \\
CCW (kilo) & 16.06 & 16.69 & 15.95 & 16.16 & 16.20 & 20.03 & 0.97 \\
HCW (\%) & 45.54 & 44.72 & 45.31 & 46.00 & 45.41 & 8.94 & 0.94 \\
CCP (\%) & 44.14 & 43.32 & 43.99 & 44.68 & 44.05 & 8.97 & 0.92 \\
BP (\%) & 50.07 & 49.77 & 50.30 & 51.36 & 50.40 & 8.81 & 0.90 \\
BL (\%) & 3.07 & 3.13 & 2.89 & 2.88 & 2.98 & 10.53 & 0.32 \\
\hline
\end{tabular}

${ }^{1} 0 \%$ glycerin replacing corn in the diet; $7 \%$ glycerin replacing corn in the diet; $14 \%$ glycerin replacing. corn in the diet; $21 \%$ glycerin replacing corn in the diet.

${ }^{2}$ Variance ratio. ${ }^{3}$ Probability. 
The assessed carcass performance features (Table 4) did not differ among feedings ( $\mathrm{P}>0.05)$. Slaughtering weight was approximately 36.62 kilos, similarly to that found by Lage et al. (2010), who assessed 0, 3, 6 and 9\% glycerin degrees. Nevertheless, these authors found quadratic behavior on slaughtering weight, depending on the amount of crude glycerin in the diet. The highest glycerin degree $(12 \%)$ presented the lowest daily weight gain.

Different crude glycerin degrees did not lead to variations $(\mathrm{P}>0.05)$ in hot carcass, cold carcass, empty body weight, cold carcass performance, biological performance, break to cooling degree (table 4). It shows that the use of crude glycerin does not cause restrictions to carcass performance.

The fact that, live weight to slaughter was not different among treatments means that the carcass would also remain the same. These results meet those by Gunn et al. (2010) who did not find any difference in carcass features after using different crude glycerin levels in lamb feed $(0,5,10,15$ and $20 \%$ in DM). The break to cooling level (Table 4) of the carcass was approximately $2.98 \%$, and it is similar to that by de Macedo Júnior et al. (2006) who found approximately $3.35 \%$. It also meets results by Almeida Junior et al. (2004), who observed losses between 3.0 and $4.0 \%$.

Crude glycerin levels also did not influence objective carcass measures $(\mathrm{P}>0.05)$ : carcass external length, leg perimeter, arm perimeter, thorax length, croup perimeter, back length and croup length (Table 5). Carcass shape (Table 5) presented quadratic response $(\mathrm{P}<0.05)$ with just $12 \%$ (peek) increase of crude glycerin in the feeding; it indicates that, up to this level, glycerin did not interfere in this parameters. The presented shape values (2.5 to 3.6) are close to those observed by Murta et al. (2009) 2.73. Their result was corroborated by "Santa Inês" lamb breed carcasses that were fed on hydrolyzed sugarcane bagasse. It is also similar to results by Pellegrin et al. (2013), whose values varied between 2.85 and 3.01, in crude glycerin diets.

Table 5. Carcass measurement of slaughtered confined lambs fed on feed containing different amounts of crude glycerin.

\begin{tabular}{|c|c|c|c|c|c|c|c|c|}
\hline \multirow[t]{2}{*}{ Parameters } & \multicolumn{4}{|c|}{ Treatments $^{1}$} & \multirow[b]{2}{*}{$\mathbf{C V}^{2}$} & \multirow[b]{2}{*}{ Regression Equation $^{3}$} & \multirow[b]{2}{*}{$\mathbf{P}^{4}$} & \multirow[b]{2}{*}{$\mathbf{R}^{2^{*}}$} \\
\hline & $\mathbf{0}$ & 7 & 14 & 21 & & & & \\
\hline External Length $(\mathrm{cm})$ & 53.00 & 55.43 & 52.62 & 53.50 & 7.35 & $\hat{\mathbf{y}}=53.60$ & 0.54 & - \\
\hline Leg perimeter $(\mathrm{cm})$ & 30.28 & 32.14 & 31.00 & 31.50 & 6.03 & $\hat{\mathbf{y}}=31.23$ & 0.32 & - \\
\hline Arm perimeter $(\mathrm{cm})$ & 5.85 & 7.00 & 6.50 & 6.62 & 15.59 & $\hat{\mathbf{y}}=6.50$ & 0.22 & - \\
\hline Thorax length (cm) & 24.57 & 24.85 & 25.62 & 24.75 & 8.60 & $\hat{\mathbf{y}}=24.96$ & 0.78 & - \\
\hline Croup perimeter $(\mathrm{cm})$ & 19.16 & 19.28 & 18.62 & 18.62 & 7.48 & $\hat{\mathbf{y}}=18.89$ & 0.72 & - \\
\hline Arm length $(\mathrm{cm})$ & 18.71 & 22.57 & 25.43 & 21.37 & 27.94 & $\hat{\mathbf{y}}=22.00$ & 0.25 & - \\
\hline Back width $(\mathrm{cm})$ & 16.28 & 16.57 & 16.75 & 16.57 & 10.55 & $\hat{\mathbf{y}}=16.55$ & 0.96 & - \\
\hline Croup length (cm) & 29.00 & 29.14 & 29.12 & 29.43 & 6.69 & $\hat{\mathbf{y}}=29.17$ & 0.98 & - \\
\hline Conformation & 2.71 & 3.14 & 3.62 & 2.50 & 24.60 & $\hat{\mathbf{y}}=2.62+0.168 x-0.008 x^{2}$ & 0.02 & 24.5 \\
\hline Finishing & 2.28 & 2.42 & 2.37 & 2.12 & 29.40 & $\hat{\mathbf{y}}=2.30$ & 0.83 & - \\
\hline $\operatorname{LEA}\left(\mathrm{cm}^{2}\right)$ & 13.12 & 14.49 & 13.54 & 13.54 & 20.37 & $\hat{\mathbf{y}}=13.66$ & 0.77 & - \\
\hline Fat thickness & 0.84 & 0.78 & 0.87 & 0.87 & 21.09 & $\hat{\mathbf{y}}=0.84$ & 0.77 & - \\
\hline
\end{tabular}

${ }^{1} 0 \%$ de glicerina na dieta em substituição ao milho; $7 \%$ de glicerina na dieta em substituição ao milho; $14 \%$ de glicerina na dieta em substituição ao milho; $21 \%$ de glicerina na dieta em substituição ao milho. ${ }^{2}$ Variance ratio. ${ }^{3}$ Regression equation $=$ Average. ${ }^{4}$ Probability. *Determination coefficient. 
The loin eye area (LEA) and the fat thickness (Table 5) were not influenced by crude glycerin inclusion in the diet $(\mathrm{P}>0.05)$. The figures for LEA were approximately $13.66 \mathrm{~cm}^{2}$, which are close to those found by Gunn et al. (2010), and Gomes et al. (2011) who have assessed confined lambs treated with crude glycerin feed. These authors were supported by the findings by Lombardi et al. (2010) who studied slaughtered lambs treated with sunflower and urea. According to Sainz (1996), LEA is a reliable way to predict muscle growth, since it has strong correlation with animal's weight to slaughter. It corroborates the lack of effect on
LEA and on weight to slaughter. Mean fat thickness $(0.84 \mathrm{~mm})$ was below that found by Pellegrin et al. (2013) who found approximately $1.65 \mathrm{~mm}$.

Only thin lamb costs ( $\mathrm{R} \$ 6.00 /$ live weight kilo) and costs from the used diets were considered in order to gather economic feasibility data (Table 6) related to the feeding cost of confined lamb. It is possible seeing that the diet with $21 \%$ crude glycerin cost $\mathrm{R} \$ 0.10$ cents (per kilo) less than that with crude glycerin diet. If such price is extrapolated to one tone of feed, the difference would be $\mathrm{R} \$ 100.00$; therefore it would become an alternative for big amounts of feed.

Table 6. Economic viability of slaughtered confined lambs, fed on feed containing different crude glycerin degrees.

\begin{tabular}{lcccc}
\hline \multicolumn{1}{c}{ Ingredients } & \multicolumn{4}{c}{ Treatments* } \\
\cline { 2 - 5 } & 0 & 7 & 14 & 21 \\
\hline 1 Thing animal cost, R\$ & 93,71 & 99,77 & 94,96 & 93,48 \\
2 Cost/Kilo of DM in total diet, R\$ & 1,08 & 1,08 & 1,04 & 0,98 \\
3 Feeding cost/animal, R\$ & 87,71 & 92,48 & 87,25 & 82,61 \\
4 Cost/kilo of live weight, R\$ & 4,25 & 4,26 & 4,33 & 4,02 \\
5 Food conversion & 3,41 & 3,39 & 3,67 & 3,62 \\
6 Feeding cost /animal and thin lamb, R\$ & 181,42 & 192,25 & 182,21 & 176,09 \\
7 enclosure gross income, R $\$$ /animal & 212,17 & 216,91 & 207,35 & 210,11 \\
8 Enclosure gross margin, $\mathrm{R} \$$ & 30,75 & 24,65 & 25,13 & 34,01 \\
\hline
\end{tabular}

* $0 \%$ glycerin replacing corn in the diet; $7 \%$ glycerin replacing corn in the diet; $14 \%$ glycerin replacing corn in the diet; $21 \%$ glycerin replacing corn in the diet.

1. Animal weight $\mathrm{x}$ weight per kilo of live weight;

2. Cost per kilo of ingredient in the total diet,

3. Total cost of the diet offered/animal number,

4. Food conversion $\mathrm{x}$ cost/kilo DM in total diet,

5. DM consumption/ weight gain,

6. Thin lamb cost sum + feeding/ animal,

7. Carcass average weight/ animal * carcass selling price $(\mathrm{R} \$ 13.00 / \mathrm{kg})$,

8. Enclosure gross income- feeding/animal and thin lamb.

Fluctuation between $\mathrm{R} \$ 82.60$ to $\mathrm{R} \$ 92.48$ was noticed after studying feeding throughout the whole confinement period; $21 \%$ crude glycerin was the cheapest diet. Food changeover was higher for the confined group with $21 \%$ crude glycerin, although its major consumption for weight gain means did not affect the final gross margin ( $\$ 34.01$ per animal) in this diet (Table 6).
Barros et al. (2015) also found positive results from the inclusion of glycerin in animals' diet $(0$, $2.65,5.33,8.06$ and $10.84 \%$ ) when they checked the economic feasibility of using it in confined lamb feed. However, these animals did not present satisfying performances, they had less salable meat. The smaller amount of salable meat and the price adopted by the market in Itapetinga - BA demonstrate the unfeasibility of using any glycerin degree. 
Lage et al. (2010), by assessing different glycerin levels $(0,3.0,6.0,9.0$ and $12 \%)$ with $36.20 \%$ glycerol, concluded that a maximum of $6 \%$ DM can be included in the diet of slaughtered lambs, fact that lead to improvement in food conversion and to economic benefits.

\section{Conclusions}

Crude glycerin inclusion in slaughtered lamb diet did not affect the animal's development, even with dry and organic mass consumption decrease. It shows that this byproduct can be used in lambs' diet.

The $21 \%$ crude glycerin inclusion may be an interesting alternative for big amounts of feed, since it appeared to be safe.

Seventy eight percent (78\%) glycerol crude glycerin to replace corn in confined lamb diets showed to be nutritionally and economically viable.

\section{Acknowledgments}

Thanks to the crude glycerin supplier, Biopar Bioenergia do Paraná.

\section{References}

ALMEIDA JUNIOR, G. A.; COSTA, C.; MONTEIRO, A. L. G.; GARCIA, A. C.; MINANI, P. D.; NERES, A. M. Desempenho, características de carcaça e resultado econômico de cordeiros criados em creep feeding com silagem de grãos úmidos de milho. Revista Brasileira de Zootecnia, Viçosa, MG, v. 33, n. 4, p. 1048-1059, 2004.

BARROS, M. C. C.; MARQUES, J. A.; SILVA, R. R.; SILVA, F. F.; COSTA, L. T.; GUIMARÃES, G. S; SILVA, L. L.; GUSMÃO, J. J. N. Viabilidade econômica do uso da glicerina bruta em dietas para cordeiros terminados em confinamento. Semina: Ciências Agrárias, Londrina, v. 36, n. 1, p. 443-452, 2015.

CARVALHO, S.; VERGUEIRO, A.; KIELING, R.; TEIXEIRA, C. G.; PIVATO, J.; VIERO, R.; CRUZ, N. A. Desempenho e características de carcaça de cordeiros das raças Texel, Suffolk e cruza Texel x Suffolk. Ciência Rural, Santa Maria, v. 35, n. 5, p. 1155-1160, 2005.
COSTA, R. G.; MEDEIROS, A. N.; GONZAGA NETO, S.; OLIVEIRA, R. J. F. Qualidade da carcaça e da carne caprina e ovina. In: SIMPÓSIO INTERNACIONAL DE CONSERVAÇÃO DE RECURSOS GENÉTICOS, 1., 2004, Recife. Anais... Recife: Dois Editores, 2004. p. 158-160.

GOMES, M. A. B.; MORAES, G. V.; MATAVELI, M.; MACEDO, F. A. F.; CARNEIRO, C. T.; ROSSI, M. R. Performance and carcass characteristics of lambs fed on diets supplemented with glycerin from biodiesel production, Revista Brasileira de Zootecnia, Viçosa, MG, v. 40, n. 10, p. 2211-2219, 2011.

GUNN, P. J.; NEARY, M. K.; LEMENAGER, R. P.; LAKE, S. L. Effects of crude glycerin on performance and carcass characteristics of finishing wheter lambs. Journal of Animal Science, Lourime, v. 88, n. 9, p. 17711776, 2010.

HANSEN, C. F.; HERNANDEZA, A.; MULLAN, B. P.; MOORE, K.; MURRAY-TREZONA, M.; KING, R. H.; PLUSKE, R. J. A chemical analysis of samples of crude glycerol from the production of biodiesel in Australia, and the effects of feeding crude glycerol to growingfinishing pigs on performance, plasma metabolites and meat quality at slaughter. Animal Production Science, Wellington, v. 49, n. 1, p. 154-161, 2009.

JOHNSON, R. R.; McCLURE, K. E. High fat rations for ruminant. II Effects of fat added to corn plant material prior to ensiling on digestibility and voluntariun intake the silage. Journal of Animal Science, Champaign, v. 36, n. 2, p. 397-406, 1973.

KREHBIEL, C. R. Ruminal and physiological metabolism of glycerin. Journal of Animal Science, Champaign, v. 86, p. 392-393, 2008. Supplement 2.

LAGE, J.; PAUlinO, R. V. P.; PEREIRA, R. G. L.; VALADARES FILHO, S. C.; OLIVEIRA, S. A.; DETMANN, E.; SOUZA, P. K. N.; LIMA, M. S. J. Glicerina bruta na dieta de cordeiros terminados em confinamento. Pesquisa Agropecuária Brasileira, Brasília, v. 45, n. 9, p. 1012-1020, 2010.

LOMBARDI, L.; JOBIM, C. C.; BUMBIERIS JUNIOR, B. H. V.; CALIXTO JUNIOR, M.; MACEDO, F. A. F. Características da carcaça de cordeiros terminados em confinamento recebendo silagem de grão de milho puro ou com adição de girassol ou uréia. Acta Scientiarum Animal Sciences, Maringá, v. 32, n. 3, p. 263-269, 2010.

MACEDO JÚNIOR, G. L.; PÉREZ, J. R. O.; ALMEIDA, T. R. V. Influência de diferentes níveis de FDN dietético no consumo e digestibilidade aparente de ovelhas Santa Inês. Ciência Agrotecnológica, Lavras, v. 30, n. 3, p. 547-553, 2006. 
MURTA, R. M.; CHAVES, M. A.; VIEIRA E SILVA, F.; BUTERI, C. B.; FERNANDES, O. W. B.; SANTOS, X. L. Ganho em peso e características da carcaça de ovinos confinados alimentados com bagaço de cana hidrolisado com óxido de cálcio. Ciência Animal Brasileira, Viçosa, MG, v. 10, n. 2, p. 438-445, 2009.

NATIONAL RESEARCH COUNCIL - NRC. Nutrient requirements of dairy cattle. $7^{\text {th }}$ ed. Washington. DC: National Academy Press, 2001. 381 p.

Nutrient requirements of small ruminants. Washington, D.C.: National Academy Press, 2007. 362 p.

ASSOCIATION OF OFFICIAL ANALYTICAL CHEMISTS - AOAC. Official methods of analysis. 15.ed. Washington: AOAC, 1990.

OSÓRIO, J. C. S. Métodos para avaliação da produção de carne ovina: in vivo na carcaça e na carne. Pelotas: Editora e Gráfica Universitária da Universidade Federal de Pelotas, 1998. 107 p.

PELlEGRIN, A. C. R. S.; MELLO, R. O.; MÜLLER, R.; CARVALHO, S.; LOPES, J. F. Glicerina bruta no suplemento e seus efeitos nas características de carcaça e nos componentes do peso vivo de cordeiros lactantes. Arquivo Brasileiro de Medicina Veterinária e Zootecnia, Belo Horizonte, v. 65, n. 5, p. 1509-1518, 2013.

PELLEGRIN, A. C. R. S.; PIRES, C. C.; CARVALHO, S.; PACHECO, S. P.; PELEGRINI, V. F. L.; GRIEBLER, L.; VENTURINI, S. R. Glicerina bruta no suplemento para cordeiros lactentes em pastejo de azevém. Ciência Rural, Santa Maria, v. 42, n. 8, p. 1477-1482, 2012.

PRADO, I. N.; MARTINS, A.; ALCADA, C. R.; ZEOULA, L. M.; MARQUES, J. A. Desempenho de novilhas alimentadas com dietas contendo milho ou casca de mandioca como fonte energética e farelo de algodão ou levedura como fonte proteica. Revista Brasileira de Zootecnia, Viçosa, MG, v. 29, n. 1, p. 278-287, 2010.

REIS, W.; JOBIM, C. C.; MACEDO, F. A. F.; MARTINS, E. N.; CECATO, U. Características da carcaça de cordeiros alimentados com dietas contendo grãos de milho conservados em diferentes formas. Revista Brasileira de Zootecnia, Viçosa, MG, v. 30, n. 4, p. 1308$1315,2001$.
SAINZ, R. D. Qualidade de carcaças e de carnes de ovinos e caprinos. In: REUNIÃO ANUAL DA SOCIEDADE BRASILEIRA DE ZOOTECNIA, 33., 1996, Fortaleza. Anais... Fortaleza: Sociedade Brasileira de Zootecnia, 1996. p. 3-14.

SAÑUDO, C.; SIERRA, I. Calidad de la canal en la especie ovina. Revista Ovino, Barcelona v. 1, n. 1, p. $127-$ $153,1986$.

SILVA SOBRINHO, A.G. Body composition and characteristics of carcass from lambs of different genotypes and ages at slaughter. 1999. Dissertation (Post Doctorate in Sheep Meat Production) - Massey University, Palmerston North.

SNIFFEN, C. J.; O'CONNOR, J. D.; VAN SOEST, P. J.; FOX, D. G.; BUSSEL, J. D. A net carbohydrate and protein system for evaluating cattle diets: II. Carbohydrate and protein availability. Journal of Animal Science, Champaign, v. 70, n. 12, p. 3562-3577, 1992.

STATISTICAL ANALYSIS SYSTEM - SAS. Statistical Analysis Systems Institute. Cary: SAS Institute, 2002.

SUDEKUM, K. H. Co-products from biodiesel production. In: GARNSWORTHY, P. C.; WISEMAN, J. (Ed.). Recent advances in animal nutrition. Nottingham: Nottingham University Press, 2008. p. 210-219.

TERRÉ, M.; NUDDA, A.; CASADO, P.; BACH, A. The use of glycerin in rations for light lamb during the fattening period. Animal Feed Science and Technology, Madrid, v. 162, n. 3, p. 262-267, 2011.

TYSON, K. S.; BOZELL, J.; WALLACE, R. Biomass oil analysis: research needs and recommendations. Colorado: Technical Report National Renewable Energy Laboratory Golden, jun. 2004. Available at: < http://www. nrel.gov/docs/fy04osti/34796.pdf>. Accessed at: 21 nov. 2013.

VAN SOEST, P. J.; ROBERTSON, J. B.; LEWIS, B. A. Symposium: carbohydrate methodology, metabolism, and nutritional implications in dairy cattle. Journal of Dairy Science, Champaign, v. 74, n. 10, p. 3583-3597, 1991.

ZANETTE, M. P.; NEUMANN, M. Confinamento como ferramenta para incremento na produção e na qualidade da carne de ovinos. Ambiência, Guarapuava, v. 8, n. 2, p. 415-426, 2012. 